\title{
A Study to Determine Yield and Yield Component Interactions on ICARDA Spring Chickpea (Cicer arietinum L.) Varieties in Eastern Mediterranean Conditions
}

\author{
Dürdane Mart \\ Eastern Mediterranean Agricultural Research Institute, Turkey.
}

\begin{abstract}
How to cite this paper: Dürdane Mart. (2021) A Study to Determine Yield and Yield Component Interactions on ICARDA Spring Chickpea (Cicer arietinum L.) Varieties in Eastern Mediterranean Conditions. International Journal of Food Science and Agriculture, 5(2), 317-321. DOI: 10.26855/ijfsa.2021.06.016
\end{abstract}

Received: April 30, 2021

Accepted: May 24, 2021

Published: June 3, 2021

*Corresponding author: Dürdane Mart, Eastern Mediterranean Agricultural Research Institute, Turkey. Email: durdanemart@yahoo.com

\begin{abstract}
This study has been conducted in years 1998 and 1999 on research fields of Eastern Mediterranean Agricultural Research Institute, at Adana/Turkey location in order to identify the yield and the yield component interactions in chickpea (Cicer arietinum L.) for Eastern Mediterranean conditions. In addition, the flowering date, plant height and tolerance to Ascochyta Blight were also taken into account as a criteria for the selection. The disribution of rainfall was also effective on the performances of lines and varieties. The area of the research was located between the geographic latitudes of $36^{0} 51^{\prime} 17.21$ North and $35^{\circ} 20^{\prime} 41.61$ East with an altitude of $23 \mathrm{~m}$. The planting was performed in December and the varieties were evaluated for their fitness to winter conditions. According to the highest and the lowest values accumulated during two years of a study at Adana location; yield values were changed in between 246.5-39.74 kg/da, flowering period was changed in between 144.0-137.8 days, plant height was changed in between $76.17-51.83 \mathrm{~cm}$ at the winter sowing conditions.
\end{abstract}

\section{Keywords}

Spring Chickpea, Varieties, Yield

\section{Introduction}

Turkey is an impotant natural gene bank for chickpeas. Chickpea is able to grow in the arid regions of Turkey, where many other crops can not be grown owing toits surviving ability under strong conditions such as poor soil, warmth and drought [1-2]. In 2019, the chickpea production was 630.000 tonnes with the sowing area of 517. 785 ha while the grain yield was $122.00 \mathrm{~kg} / \mathrm{da}$ [3]. For the Eastern Mediterranean region, chickpea is a crucial plant in the sowing alternation. Being rich in protein and leaving a high nutrition soil afterwards are main beneficial points for legumes to become essential crop in the sowing alternation [4]. In addition to the use of edible legumes in human nutrition, grains and stems are also used in animal feeding. Furthermore, the digestibility ratings (78\%) of the proteins found in legume stalks and grains are significantly higher than those of cereals.

In edible grain legumes, it is desired that the highyield and quality as well as the components that effect the yield are consistent and optimum. For this reason, the yield and quality values of the elite varieties should stay at good levels. In this research, it was aimed to determine the adaptations of the related genotypes to the regional conditions in terms of yield and yield components of the chickpea cultivars in Eastern Mediterrraneanregion at Adana location for two years and at the winter sowing [5-6]. 


\section{Materials and Methods}

In this study, a total of 23 spring chickpeas (Cicer arietinum L.) obtained from ICARDA were evaluated in the Eastern Mediterranean region and the native chickpea landraces were used as controls. The experiments were planted in December under winter conditions at the Adana location and the observations and evaluations were made based on 23 chickpea varieties.

The research was carried out at the Eastern Mediterranean Agricultural Research Institute trial sites during the years 1998 and 1999. The study was conducted with three replications according to randomized block trial design. The parcel was formed from 4 rows with $45 \mathrm{~cm}$ between rows and $8 \mathrm{~cm}$ above the rows. The hand sowing was applied in this study. The plot and the harvest plot area in trial was $5 \mathrm{~m} \times 1.8 \mathrm{~m}=9 \mathrm{~m}^{2}$; The harvest for each plot were made by hand. In both years, commercial fertilizers were given after sowing as $3 \mathrm{~kg} / \mathrm{da} \mathrm{N}$ and $6 \mathrm{~kg} / \mathrm{da} \mathrm{P}_{2} \mathrm{O}_{5}$. The climatic chracteristics during the production period such as monthly rainfall $(\mathrm{mm})$, temperature $\left({ }^{0} \mathrm{C}\right)$ and relative humidity $(\%)$ rates of Adana where the research was conducted can be seen in Figure 1. Adana's avarage climate values for many years and for the specific two years in which the study was conducted are given in Table 1.

Table 1. Eastern Mediterranean region (Adana) during long years and the years of research (1998-1999)

\begin{tabular}{|c|c|c|c|c|c|c|c|c|c|}
\hline \multirow{2}{*}{ Months } & \multicolumn{3}{|c|}{ Average Temparature $\left({ }^{0} \mathrm{C}\right)$} & \multicolumn{3}{|c|}{ Rain (mm) } & \multicolumn{3}{|c|}{ Moisture (\%) } \\
\hline & Long Years (1929-90) & 1. Year & 2. Year & Long Years (1929-90) & 1. Year & 2. Year & Long Years (1929-90) & 1. Year & 2. Year \\
\hline November & 15.1 & 16.2 & 15.4 & 67.2 & 13.6 & 107.3 & 63 & 62.2 & 74.7 \\
\hline December & 11.1 & 12.7 & 10.7 & 118.1 & 122.5 & 177.8 & 66 & 76.8 & 79.3 \\
\hline January & 9.9 & 9.2 & 8.5 & 111.7 & 38.0 & 46.4 & 66 & 67.5 & 69.6 \\
\hline February & 10.4 & 8.0 & 9.9 & 92.8 & 67.0 & 6.3 & 66 & 67.6 & 63.9 \\
\hline March & 13.1 & 10.2 & 11.3 & 67.9 & 19.4 & 92.9 & 66 & 65.3 & 71.7 \\
\hline April & 17.1 & 14.2 & 18.2 & 51.4 & 104.4 & 56.2 & 69 & 72.9 & 68.7 \\
\hline May & 21.4 & 22.6 & 21.6 & 46.7 & 20.1 & 32.9 & 67 & 68.2 & 70.5 \\
\hline Jun. & 25.2 & 25.5 & 26.2 & 22.4 & 11.4 & 0.2 & 66 & 73.3 & 74.9 \\
\hline Jul. & 29.7 & 28.7 & 28.6 & 5.4 & 0.9 & 9.7 & 68 & 72.7 & 77.9 \\
\hline Total & & & & 583.6 & 397.3 & 529.7 & 66.3 & 69.6 & 72.35 \\
\hline
\end{tabular}

In this study, variance analysis was applied according to randomized blocks trial design in the MSTAT-C package program. The average valueswere grouped by LSD 5\%.

\section{Results and Discussion}

According to the results of analysis of variance (ANOVA) in 0.01 significance level that obtained in the study, the year was significant for the yield, the flowering date and the plant height while the variety was significant for the yield and the plant height. On the other hand, we need to consider that the annual precipitation rates are also highly effective on the yield and the other components. The variance analysis results are given in Table 2 .

Table 2. Results of Variance Analysis of Specified Chickpea Cultivars Grown in Different Yearsduring two years in Eastern Mediterranean Region

\begin{tabular}{ccccc}
\hline Variation sources & Degrees of freedom & Seed Yield & $\begin{array}{c}\text { Squares Mean } \\
\text { Flowering (day) }\end{array}$ & Plant Height (cm) \\
\hline Replication & 2 & $6,925.508$ & 16.355 & 52.457 \\
Variety & 22 & $22,290.996^{* *}$ & 10.586 & $244.360^{* *}$ \\
Year & 1 & $545,568.113^{* *}$ & $3,042.783^{* *}$ & $3,331.043^{* *}$ \\
Variety xYear & 22 & $24,212.344^{* *}$ & $19.222^{*}$ & $353.165^{* *}$ \\
Error & 90 & $3,836.241$ & 9.851 & 77.894 \\
General & 137 & $1,927,754.278$ & $4,617.884$ & $23,591.913$ \\
\hline
\end{tabular}

* $5 \%$ significant level, ** $1 \%$ significant level.

As seen in Table 3, the avarage value of respective two years for the grain yield was $141.594 \mathrm{~kg} / \mathrm{da}$, the number of flowering days was 139.363 days and the plant height was $65.57 \mathrm{~cm}$.

Table 3. The avarage values for two respective yearsin grain yield, flowering time and plant height for the chickpea varieties

\begin{tabular}{cccc}
\hline Years & Seed Yield $(\mathrm{kg} / \mathrm{da})$ & Flowering Days (day) & Plant Height $(\mathrm{cm})$ \\
\hline 1. Year & 204.470 & 144.058 & 60.652 \\
2. Year & 78.718 & 134.667 & 70.478 \\
Avarage & 141.594 & 139.3625 & 65.565 \\
\hline
\end{tabular}

Values of the same letter group are not different from EGF 5\% test. 
As can be seen from Table 4, when the grain yields obtained from varieties were examined, the highest yields were found at FLIP 92-142C (205.5 kg/da), FLIP 93-178C (194.7 kg/da) in the first year and at FLIP 94-166C (424.2 kg/da), FLIP 93-133C (384.6 kg/da) in the second year. The lowest values were found at FLIP 93-133C $(24.56 \mathrm{~kg} / \mathrm{da})$ in the first year and at FLIP 92-202C (23.48 kg/da) in the second year. In addition to the low amount of precipitation in the first and the second years, the irregularity of the distribution also affected the yields in both years. The highest values were obtained for FLIP 94-88C (246.5 kg/da) and FLIP 93-58C (43.07 kg/da) and FLIP 93-51C (47.06 kg/da) for the two year average grain yields. In their study [7] were investigated the interactions between the yield and the yield components on 30 chickpea lines. They stated that the yield and the number of pods have strong positive correlation and selection based on the pod number expected to be effective. [8] were conducted a study on 23 chickpea lines for two years under the winter conditions in Eastern Mediterranean region and they found the values ranged between 67.9-84.2 cm for plant height, 16-28 for number of pod, 26.7-37.5 g for 100-grain weight, $28.37 \%$-34.93\% for harvest index and $178.6-271.9 \mathrm{~kg} / \mathrm{da}$ for the grain yield [9-12].

Table 4. Grain Yield, Flowering Date, Anthracnose and Plant Length Values in Different Two Years for Twenty Five Chickpea Lines in Eastern Mediterranean Region

\begin{tabular}{|c|c|c|c|c|c|c|c|c|c|c|c|}
\hline \multirow{2}{*}{$\begin{array}{c}\text { Chickpea } \\
\text { Variety }\end{array}$} & \multicolumn{3}{|c|}{ Seed Yield(kg/da) } & \multicolumn{3}{|c|}{ Flowering days(day) } & \multicolumn{2}{|c|}{ Ascochyta Blight (1-9) } & \multicolumn{3}{|c|}{ Plant height(cm) } \\
\hline & 1. Year & 2. Year & Average. & 1. Year & 2. Year & Average. & 1. Year & 2. Year & 1. Year & 2. Year & Average \\
\hline FLIP92-202C & $122.8 \mathrm{f}-\mathrm{m}$ & $23.48 \mathrm{~m}$ & 148.9a-d & $142.3 \mathrm{~b}$ & 133.7 de & $144.0 \mathrm{a}$ & 3 & 7 & 46.33no & 74.33 b-1 & 61.17 b-e \\
\hline FLIP92-105C & 175.0e-h & 298.8 b-d & $157.8 \mathrm{a}-\mathrm{d}$ & $145.7 \mathrm{ab}$ & 147.7 a & $139.5 \mathrm{ab}$ & 3 & 2 & $76.00 \mathrm{~b}-\mathrm{h}$ & $57.00 \mathrm{j}-\mathrm{o}$ & 75.67 a \\
\hline FLIP92-142C & 205.5 d-f & 82.44h-m & 95.59c-e & $144.0 \mathrm{ab}$ & 133.3 de & $139.5 \mathrm{ab}$ & 3 & 4 & 78.33 a-d & 69.00c-k & $68.00 \mathrm{a}-\mathrm{c}$ \\
\hline FLIP92- 147C & 110.1f-m & 339.9a-c & 139.4b-e & 135.0 de & 145.0ab & $140.0 \mathrm{ab}$ & 3 & 2 & $73.00 \mathrm{~b}-1$ & $61.001-\mathrm{m}$ & $67.50 \mathrm{a}-\mathrm{d}$ \\
\hline FLIP 92- 31C & $123.7 \mathrm{f}-\mathrm{m}$ & $120.5 f-m$ & $114.8 c-e$ & $143.7 \mathrm{ab}$ & 132.3 de & $138.3 \mathrm{~b}$ & 3 & 3 & $73.00 \mathrm{~b}-1$ & 91.33 a & 63.00 a-e \\
\hline FLIP 93- 51C & $67.481-\mathrm{m}$ & $313.0 \mathrm{bc}$ & $47.06 \mathrm{e}$ & 135.3 de & $146.7 \mathrm{ab}$ & $138.2 \mathrm{~b}$ & $5-6$ & 3 & $63.00 \mathrm{~g}-\mathrm{k}$ & $57.33 \mathrm{j}-\mathrm{o}$ & 68.83 a-c \\
\hline FLIP 93- 58C & $133.3 \mathrm{f}-\mathrm{k}$ & $63.701-\mathrm{m}$ & 43.07 e & $144.3 \mathrm{ab}$ & 134.7de & $138.8 \mathrm{~b}$ & 3 & 4 & $73.67 \mathrm{~b}-1$ & $77.33 \mathrm{a}-\mathrm{f}$ & 53.67 de \\
\hline FLIP 93-64C & $145.5 f-1$ & 298.4b-d & 116.5 c-e & 135.7de & $146.3 \mathrm{ab}$ & $139.3 \mathrm{ab}$ & 4 & 2 & $61.331-1$ & 55.33 k-o & 69.67 abc \\
\hline FLIP 93- 78C & 194.7e-g & 40.89j-m & 90.26 c-e & $142.3 \mathrm{~b}$ & 130.7 e & $138.5 \mathrm{~b}$ & 3 & 6 & 47.67l-o & $61.001-\mathrm{m}$ & $51.83 \mathrm{e}$ \\
\hline FLIP 93-118C & $34.89 \mathrm{k}-\mathrm{m}$ & $139.0 \mathrm{f}-\mathrm{j}$ & 102.7 c-e & 134.3 de & 145.0ab & $138.5 \mathrm{~b}$ & 5-7 & 3 & $78.33 \mathrm{a}-\mathrm{d}$ & $56.33 \mathrm{j}-\mathrm{o}$ & 69.17abc \\
\hline FLIP93 - 119C & $69.561-\mathrm{m}$ & $32.81 \mathrm{~lm}$ & 135.8 b-e & $143.7 \mathrm{ab}$ & 135.0de & $140.0 \mathrm{ab}$ & 5 & 6 & $61.331-1$ & 85.33ab & $72.67 \mathrm{ab}$ \\
\hline FLIP 93-133C & $24.56 \mathrm{~m}$ & $384.6 \mathrm{ab}$ & 39.74 e & 132.7 de & $142.0 \mathrm{~b}$ & $138.0 \mathrm{~b}$ & 7 & 3 & 76.33b-g & $64.67 \mathrm{~d}-\mathrm{k}$ & 60.67 b-e \\
\hline FLIP 94- 144C & 59.48 1-m & $57.781-\mathrm{m}$ & 190.6 a-c & $143.0 \mathrm{ab}$ & 133.7 de & $140.5 \mathrm{ab}$ & 5 & 5 & $46.00 \quad 0$ & $64.67 \mathrm{~d}-\mathrm{k}$ & 63.00 a-e \\
\hline FLIP94 - 166C & $26.67 \mathrm{~m}$ & 424.2 a & $230.2 \mathrm{ab}$ & 134.7 de & $143.3 \mathrm{ab}$ & $138.7 \mathrm{~b}$ & 6 & 3 & $61.33 \quad 1-1$ & $63.33 \mathrm{f}-\mathrm{k}$ & 76.17 a \\
\hline FLIP 94- 176C & 96.22g-m & $68.741-\mathrm{m}$ & $188.4 \mathrm{a}-\mathrm{c}$ & $144.7 \mathrm{ab}$ & 135.0de & $140.7 \mathrm{ab}$ & 5 & 6 & $79.00 \mathrm{a}-\mathrm{c}$ & $64.00 \mathrm{e}-\mathrm{k}$ & $67.33 \mathrm{a}-\mathrm{d}$ \\
\hline FLIP 94-182C & 136.7f-j & 273.2 c-e & 169.6a-d & 134.0de & 141.7 bc & $138.5 \mathrm{~b}$ & 4 & 3 & $60.331-n$ & $60.331-n$ & 58.17 c-e \\
\hline FLIP 94- 8C & 137.9f-j & $40.22 \mathrm{j}-\mathrm{m}$ & 85.93de & $143.3 \mathrm{ab}$ & 134.3de & $140.0 \mathrm{ab}$ & 3 & 6 & $47.67 \mathrm{l}-\mathrm{o}$ & 79.33 a-c & 70.83 a-c \\
\hline FLIP 94 - 61C & $42.67 \mathrm{j}-\mathrm{m}$ & $110.4 f-m$ & $221.2 \mathrm{ab}$ & 133.7de & $144.0 \mathrm{ab}$ & $137.8 \mathrm{~b}$ & 5 & 3 & 56.00j-o & 46.00 o & 64.67a-e \\
\hline FLIP 94- 88C & 106.3f-m & $121.2 \mathrm{f}-\mathrm{m}$ & 246.5 a & $144.7 \mathrm{ab}$ & $136.7 \mathrm{~cd}$ & $139.2 \mathrm{ab}$ & 3 & 3 & 74.33 b-1 & 68.33 c-k & 63.67 a-e \\
\hline FLIP 94- 105C & 99.19g-m & $373.0 \mathrm{a}-\mathrm{c}$ & 156.7a-d & 132.3de & $144.3 \mathrm{ab}$ & $138.0 \mathrm{~b}$ & 4 & 2 & 64.00 e-k & $61.331-1$ & $69.83 \mathrm{a}-\mathrm{c}$ \\
\hline FLIP 94- 111C & 131.1f-l & 87.70 h-m & 115.8 c-e & $144.0 \mathrm{ab}$ & 135.7de & $140.3 \mathrm{ab}$ & 3 & 4 & $76.00 \mathrm{~b}-\mathrm{h}$ & 77.67 a-e & 57.17 c-e \\
\hline FLIP94 - 150C & $140.4 f-j$ & 311.7 bc & $230.3 \mathrm{ab}$ & $136.0 \mathrm{~d}$ & $145.0 \mathrm{ab}$ & $140.0 \mathrm{ab}$ & 3 & 3 & 69.33 c-k & $62.00 \mathrm{~h}-\mathrm{k}$ & 69.50 a-c \\
\hline Local Chickpea & $56.001-\mathrm{m}$ & $67.701-\mathrm{m}$ & 189.7 a-c & $142.3 \mathrm{~b}$ & 133.0de & $139.0 \mathrm{ab}$ & 5 & 5 & $47.00 \mathrm{~m}-\mathrm{o}$ & $69.67 c-j$ & 65.83 a-e \\
\hline $\mathrm{F}$ & $*$ & * & $*$ & $*$ & $*$ & $*$ & & & $*$ & $*$ & $*$ \\
\hline CV(\%) & & 43.743 & & & 2.252 & & & & & 13.461 & \\
\hline
\end{tabular}

CV: Variation of Cofficient; * Significant.

In terms of the number of flowering days, the highest value were obtained from FLIP 92-105C (145.7 days) and the lowest value from FLIP 94-105C (132.3 days) in the first year (Table 4). In the second year, the highest value were determined from FLIP 92-105C (147.7 days) and the lowest value from FLIP 93-78C (130.7 days). The irregular distribution of the amount of rainfall in April for the both years has had a negative effect on the flowering date especially in the flowering period of the first year. The average number of flowering days for two years varied from 144.0 to 137.8 days. Falling precipitation in this period also increased the intensity of anthracnose disease [13-14] was conducted a study with three different chickpea varieties which were sown in five different sowing time during three years and stated that the flowering time and plant height could be reduced with late sowing and also mentioned that the annual yield would fluctuate raleted to the annual rainfall and the soil moisture [15].

For the plant height, the highest value was obtained from FLIP 94-176C $(79.00 \mathrm{~cm})$ and the lowest value was 
detected from FLIP 94-144C $(46.00 \mathrm{~cm})$ in the first year (Table 4). The highest value was determined from FLIP 92-31C $(91.33 \mathrm{~cm})$ and the lowest value was from FLIP 94-61C $(46.00 \mathrm{~cm})$ in the second year. Two-year mean plant height values ranged from 76.17 to $51.83 \mathrm{~cm}$. Our findings for plant height was matched with the findings in a study published by [16].

\section{Conclusion}

As a result, it was determined that in the selection of the efficient lines and varieties suitable for the winter cultivation in which the research was carried out, it was found that the early flowering date and the plant height suitable for machine harvestwere the important components for the optimumyield.

Anthracnose disease has also been influential in the selection of lines. The study conducted from [17-20] was evaluated 34 chickpea varieties for their tolerance/resistance against the local pathotypes of anthracnose disease in Eastern Mediterranean region for two years during 2014/2015 and they found that the Pathotype- 1 has the less pathogenicity while the Pathotype-IV has the most pathogenicity. The grain yield obtained from the winter and the early-spring sowing times were higher than the late-spring sowing time. It can be recommended that the chickpea varieties which are resistant to Ascochyta blight (Ascochyt rabiei) should be sown in winter or as early as in spring depending on the temperature and the soil moisture content in the East Mediterranean Region. The lines and varieties named FLIP 94-88C, FLIP 94-150C, FLIP 94-166C and FLIP 94-61C were evaluated as promising breeding materials for the winter conditions.

\section{References}

[1] Eser, D. (1978). Edible Grain Legumes, Ankara University, Faculty of Agriculture, Lecture script. P. 98, Ankara.

[2] Zulkadir, G., Colkesen, M., İdikut, L., Cokkizgin, A., Girgel, U., Tanrikulu, A., Guneş, M. (2015). Identifying the effect of plant density on yield and yield components for Lentis (Lens culinaris Medic.) under climatic conditions of Kahramanmaraş. Harran Agriculture and Food Science, 19(3), 135-143.

[3] Anonymous. (2021). FAO. https:// www. fao. org/ faostat/.

[4] Dahıya, B. S., Kapoor, A. C., SolankI, I. S., Waldıa, R. S. (1982). Effect of Cultivar and Location on Seed Protein in Chickpea (Cicer arietinum L.). Exp. Agric., 18: 289-292.

[5] Singh, K. B., Malhotra, R. S., Saxena, M. C., Bejiga, G. (1997). Superiority of Winter Sowing over Traditional Spring Sowing of Chickpea in the Mediterranean Region. Agronomy Journal, 89(1), 112-118.

[6] Saxena, M. C. (1980). Recent Advences in Chickpea Agronomy. In Proceedings of the First International Workshop on Chickpea Improvement, 28 Feb-2 Mar 1979. Icrisat, Hyderabat, India, s. 89-96.

[7] Katıyar, R. P., Singh, H. G. (1987). Interrelationships of Physiological Attributes with Seed Yield and It's Components in Chickpea. Farm Science Journal, 2(2), 125-130.

[8] Anlarsal, A. E., C. Yücel, D. Özveren. (1999). A study to identify the parameters of yield and yield components for Chickpea in Eastern Mediterranean region. Turkish Field Crop Congress. Third edition (Forage Crops and Edible Grain Legumes), pp. 342-347, 15-18 November, Adana.

[9] Mart, D., Derya Yücel, Meltem Türkeri. (2015). Evaluation of yield and morphological characteristics of chickpea (Cicer arietinum L.) genotypes at winter sowing time in Çukurova region, Turkey XI. Field Plants Congress, Canakkale, 19-23 September, 2015.

[10] Mart, D., Anlarsal, Emin. (2007). Determination of Genotype X Environmental Interference due to Some Properties of Chickpea (Cicer arietinum L.) in Cukurova Conditions. Journal of Field Plants Research Institute, Cilt: 16, Say1: 1-2, 2007, ISSN 1302-4310, Ankara.

[11] Mart, D., Cansaran, E., Karaköy, T. (2007). Determination of Yield and Yield Components of Some Chickpea (Cicer arietinum L.) Line and Varieties in Cukurova Conditions and Their Relations Turkey VII. Field Plants Congress, 25-27 June 2007, Erzurum (Poster).

[12] Mart, D., Anlarsal, E. (2001). A Research on Genotype X Environmental Interactions and Adaptation Abilities Determination of Some Important Features of Chickpea (Cicer arietinum L.) in Cukurova Conditions. Turkey 4th Field Crops Congress, 17-21 September 2001, Tekirdağ.

[13] Necip Nalçacı, Feyza Nur Kafadar, Ali Özkan, Ayhan Turan, Selçuk Başbuğa, Ayşe Anay, Dürdane Mart, Ender Öğut, Kamil Sarpkaya, Omar Atik, Canan Can. (2021). Epiphytotics of chickpea Ascochyta blight in Turkey as influenced by climatic factors. Journal of Plant Diseases and Protection, https://doi.org/10.1007/s41348-021-00458-7.

[14] Bejiga, G. and Tollu, A. (1982). The Influence of Plantings Dates on the Yield of Three Chickpea (Cicer a Khorgade, P. W. Narkhede, M. N., and Raut, S. K. 1985. Genetic Variability Studies in Chickpea. International Chickpea Newsletter, 12; 12-13).

[15] Sehirali, S. (1988). Food Legumes, Ankara Üni. Faculty of Agricultural Publications, 1089, Ankara, 435 s.

[16] Doğan, Y., Çiftçi, V., Ekinci, B. (2015). The effect of different plant densities on yield and some yield components for chickpea (Cicer arietinum L.) under ecological conditions of Mardin. Iğdır Univ. J. Inst. Sci. \& Tech., 5(1): 73-81.

[17] Imtiaz, M., Abang, M. M., Malhotra, R. S., Ahmed, B., Udupa, S. M., Baum, M. (2011). Pathotype IV, a new and highly virulent pathotype of Didymella rabiei, causing Ascochyta Blight in chickpea in Syria. Plant Dis., 95: 1192. 
[18] Mart, D., Dumlu, S., E., Türkeri, M., Yücel, D., Karaköy, T., Öktem, G., Atmaca, E., Çankaya, N. (2016). Evaluation of chickpea (Cicer arietinum L.) varieties for yield and morphological features in several geographic regions. Second International Legume Society Conference (2ILSC) and Ascochyta Workshop. 10-14 October 2016. Portugal.

[19] Can, C., Kafadar, F. N., Özkan, A., Turan, A., Kuscali, N., Nalcaci, N., Basbuga, S., Polatbilek, H., Yasar, A., Bulgak, S., Sarpkaya, K., Isler, D., Anay, A., Mart, D., Ogut, E., Özkilinç, H., Özyigit, İ. (2016). Correlation of Ascochyta blight severity in chickpea with pathotypes, mating type, altitude, nodulation and weed density in Turkey. IV International Ascochyta Workshop, 10-11 October, Tróia-Portugal. P. 22.

[20] N. Nalcaci, A. Turan, S. Basbuga, F. N. Kafadar, D. Isler Ceyhan, A. Anay, D. Mart, E. Ogut, K. Sarpkaya, and C. Can. (2021). Virulence and Mating Type Distribution of Didymella rabiei in Chickpea Growing Areas of Turkey, J. Agr. Sci. Tech., 2021, Vol. 23(1): 209-220 (JAST). 